\title{
KESEPADANAN PRAGMATIK DALAM PENERJEMAHAN SATIRE
}

\author{
Rahmat Wisudawanto \\ Fakultas Ilmu Pengetahuan Budaya, Universitas Indonesia \\ Pos-el: wisudawanto@gmail.com
}

\begin{abstract}
Abstrak
Issue terkait dengan kesepadan masih menimbulkan perdebatan tetapi juga menjadi masalah yang penting dalam kajian terjemahan. Kesepadanan masih menjadi landasan penting dalam pengembangan model pengukuran kualitas terjemahan. Artikel ini akan berusaha menjelaskan kesepadanan pragmatik yang dicapai dalam penerjemahan tuturan satire. Selain itu, artikel ini juga akan menunjukkan frekuensi kesepadanan pargmatik yang dicapai oleh penerjemah dalam menerjemahkan tuturan satire pada novel animal farm dan terjemahannya. Hasil penelitian menunjukkan bahwa terdapat tiga jenis kesepadanan pragmatik yang dicapai oleh penerjamah yaitu kesepadanan ilokusi, implikatur dan jarak relevansi. Kesepadanan yang dihasilkan penerjemah dalam penerjemahan tuturan satire dapat menunjukkan keberhasilan penerjemah dalam mengalihkan pesan satire.

Kata Kunci: Penerjemahan, Kesepadanan, Pragmatik, Satire.
\end{abstract}

\begin{abstract}
The issues related to equivalence are still debatable but it has also become an important issue in translation studies. Equivalence is still significant as the basis of development in assessing the translation quality model. This article will attempt to explain the pragmatic equivalence achieved in translating satirical utterances. Besides, this article will also show the frequency of pragmatic equivalences achieved by translators in translating satirical utterances in Animal Farm novels and their translations. The results show that there were three types of pragmatic equivalence achieved by the speaker, namely illocutionary equivalence, implicature, and relevance degree. The equivalence produced by the translator in translating satirical utterances can show the success of the translator in transferring the satirical message.
\end{abstract}

Keywords: Translation, Equivalence, Pragmatics, Satire

$$
\begin{aligned}
& \text { Open Access } \\
& \text { (c) (1) (0) }
\end{aligned}
$$





\section{PENDAHULUAN}

Penerjemahan sebagai tindak komunikasi menunjukkan bahwa terdapat proses penyampaian pesan antara penerjemah dan pembaca. Dalam usaha penyampaian pesan, penerjemah berusaha menata pesan yang direpresentasikan dalam bentuk ujaran atau tuturan pada teks terjemahan yang dihasilkannya. Adapun pembaca berusaha menata menafsirkan ujaran untuk mendapatkan pesan yang dimaksud oleh penerjemah. Dengan demikian, keberhasilan komunikasi salah satunya ditentukan dengan keberhasilan pemahaman pesan oleh pembaca. Selanjutnya, pada konteks penerjemahan sebagai tidak komunikasi, penerjemah harus dapat mempertahankan kesepadanan pesan dalam produk terjemahannya. (Catford, 1965) menyatakan bahwa the central problem of translation practice is that of finding TL (Target Language) translation equivalents. A central task of translation theory is that of defining the nature and conditions of translation equivalence. Oleh karena itu. kesepadanan menjadi hal penting dalam sebuah aktivitas penerjemahan.

Terdapat berbagai kesepadanan yang harus dicapai penerjemah dalam menghasilkan terjemahan. Kesepadanan yang dihasilkan oleh penerjemah tidak hanya kesepadanan makna (semantik) saja namun kesepadanan maksud (pragmatik) juga harus dapat dicapai. Konsep kesepadanan dalam penerjemahan pertama kali dikemukakan oleh(Jakobson, 1959). Jacobson mengenalkan istilah equivalance with difference yang menjadi masalah utama dalam bahasa dan istilah tersebut kemudian memunculkan asimetri langsung dalam bahasa yang menjadi inti dari kajian penerjemahan. Selanjutnya, istilah equivalence (kesepadanan) ini kemudian dikembangkan oleh (Nida, 1964) dengan formal correspondence dan dynamic equivalance. Pada formal correspondence lebih menitik beratkan pada kesepadanan makna yang harus dicapai dalam sebuah terjemahan sedangkan dynamic equivalance lebih berfokus pada kesepadanan alami sebuah pesan dengan bahasa sasaran. Dengan kata lain, kesepadanan dynamic lebih mengacu kesepadanan maksud pada bahasa sasaran dengan lebih menekankan pada efek yang dihasilkan dari sebuah terjemahan. Dengan demikian, kesepadanan dynamic ini merupakan kesepadanan pragmatik, (Chen, 2020)

Pada kasus penerjemahan tuturantuturan satire, kesepadanan pragmatik sangat dipenting karena tuturan-tuturan satire mempunyai maksud-maksud tertentu. Oleh karena itu, sejauh mana penerjemah dapat menyajikan maksud yang sama dalam karya terjemahaannya dapat membuat pembaca sasaran mendapatkan efek satire 
yang sama dengan teks sumbernya. Hal ini disebabkan pesan satire terkandung dalam maksud dari tuturan-tuturan. Pada kajian pragmatik, maksud-maksud tuturan dapat dikaji melalui ilokusi. (Searle, 1969) mengklasifikasi ilokusi kedalam bentuk representatif, direktif, komisif, ekspresif, dan deklarasi. Selain itu, maksud-maksud satire yang sering dinyatakan dalam bentuk implisit membuat pemahamman maksudmaksud tersebut perlu melibatkan analisis implikatur. Konsep dasar dari implikautur menyatakan bahwa apa yang dikatakan berbeda dengan apa yang dimaksudkan. Oleh karena itu, implikatur tidak perlu untuk di ekspresikan secara eksplisit(Wijana, 1996). (Grice, 1975) mengklasifikasikan implikatur menjadi conventional implicature dan conversational implicature. Conventional implicature bersifat umum dan konvensional. Hal ini berarti bahwa secara umum setiap orang telah mengetahui dan memahami arti atau implikasi dari suatu kasus. Oleh karena itu, dalam memahami implikatur ini, pendengar atau pembaca diasumsikan sudah memiliki pengalaman dan pengetahuan umum yang sama. Adapun conversational implicature (implikatur percakapan) muncul dalam sebuah percakapan sehingga implikatur ini bersifat sementara dan tidak konvensional secara langsung dengan ujaran yang
diucapkan(Levinson, 1991).Selanjutnya analisis relevansi juga dibutuhkan untuk melihat apakah terjemahan yang dihasilkan dapat dipahami oleh pembaca dengan efek kontekstual dan upaya pemrosesanya, (White, 2011). Efek kontekstual terkait dengan contextual implication yang dilibatkan dalam mengahasilkan tuturan sedangkan upaya pemrosesan lebih mengacu kepada usaha mitra tutur untuk memahami maksud dari tuturan yang disampaikan oleh penutur. Pada analisis relevansi ini semua tuturan yang dihasilkan penutur memiliki relevansinya masingmasing akan tetapi yang menjadi permasalahannya adalah apakah mintra tutur memerlukan upaya pemrosesan yang tinggi atau rendah.

Selanjutnya, pencapaian kesepadanan penerjemahan satire turut menentukan keberhasilan penerjemah dalam mengalihkan pesan satire dalam bahasa sasaran. Selain itu, pencapaian kesepadanan satire juga dapat membuat terjemahan yang dihasilkan oleh penerjemah menghadirkan efek satire yang sama bagi pembaca sasaranya. Kajian terkait dengan kesepadanan pragmatic telah dilakukan oleh beberapa peneliti sebelumnya. (Aruna, 2018) mengkaji tentang pentingnya kesepadanan pragmatik dalam penerjemahan. Lebih lanjut, Aruna melalui hasil kajiannya menunjukkan bahwa dalam 
melakukan kegiatan penerjemahan perlu dipertimbangkan latar belakang informasi dalam menginterpretasikan makna sehingga interpretasi makna akan tepat jika melibatkan konteksnya. Penelitian yang relevan dengan penelitian ini juga dilakukan oleh (Yuliasri, 2016). Yuliasri melakukan penelitian terhadap tuturan-tuturan yang mengandung humor. Ia memfokuskan kajiannya pada teknik penerjemahan dan kesepadanan pragmatik. Pada analisis teknik penerjemahan, penelitian tersebut menunjukkan bahwa tuturan-tuturan humor diterjemahkan dengan berbagai macam teknik yang $96.87 \%$ menghasilkan terjemahan yang sepadan secara maksud sedangkan analisis kesepadanan pragmatik dilihat dari kajian implikatur. Dengan demikian, kajian tertang kesepadanan pragmatik yang dicapai oleh penerjemah dalam menerjemahkan tuturan-tuturan satire dengan mengidentifikasi kategori-kategori kesepadanan berdasarkan kerangka analisis pragmatik menjadi signifikan untuk dikaji karena hal ini dapat menentukan keberhasilan pengalihan pesan satire pada teks bahasa sasaran.

\section{METODE PENELITIAN}

Penelitian ini dilakukan untuk mengidentifikasi dan menjelaskan kategori kesepadanan pragmatik pada penerjemahan satire. Sumber data penelitian ini menggunakan novel novel animal farm dan terjemahannya dalam bahasa Indonesia dengan judul binatangisme. Pengumpulan data penelitian ini dilakukan reduksi data untuk mendapatkan tuturan satire dalam novel. Reduksi data tersebut dilakukan dengan mendasarkan pada karakteristik satire yang diungkapkan oleh (LeBoeuf, 2007) yang meliputi: (1) satire berisi ktitik terhadap sikap dan perilaku yang buruk, (2) satire menggunakan ironi. (3) Satire berbentuk implisit. Penelitian ini menggunakan metode deskriptif kualitatif dengan analisis linguistik. Kerangka analisis pragmatik digunakan dalam artikel ini sebagai kerangka analisis. Analisis ini memfokuskan kesepadanan pragmatik pada novel animal farm dan terjemahannya. Untuk menganalisis kesepadanan pragmatis, tuturan satire pada teks sumber dan teks target dibandingkan. Kemudian, ilokusi atau daya ilokusi tuturan dianalisis berdasarkan klasifikasi ilokusi oleh (Searle, 1969) yaitu: representatif, direktif, komisif, ekspresif, dan deklarasi. Jika teks sumber dan teks sasaran memiliki jenis ilokusi dan daya ilokusi yang sama maka keduanya dianggap sepadan secara pragmatis. Selanjutnya, cara yang sama juga diterapkan dalam menganalisis hasil terjemahan satire untuk melihat kesepadanan implikatur dan relevansinya. Secara sederhana proses analisis yang dilakukan dalam penelitian ini 
dapat dilihat pada tahapan-tahapan berikut:

(1) menetukan tuturan-tuturan yang mengandung pesan satire, (2) analisis implikatur, (3) analisis ilokusi dan daya ilokusi, (3). analisis jarak relevansi dan (4) menjelaskan frekuensi kesepadanan pragmatik.

\section{HASIL DAN PEMBAHASAN \\ a. Kriteria Satire}

Tuturan satire pada penelitian ini didasarkan pada kriteria satire munurut (LeBoeuf, 2007). Berdasarkan kriteria yang dinyatakan oleh Le Beoeuf, penelitian ini menemukan dua dari tiga kriteria satire, yaitu (1) Satire berisi kritik terhadap sikap dan perilaku buruk, dan (2) Satire menggunakan ironi. Distribusi data pada analisis menunjukkan bahwa kriteria satire yang dominan pada novel animal farm adalah satire menggunakan ironi. Ironi merujuk pada suatu acuan yang ingin mengatakan sesuatu dengan makna atau maksud berlainan dari apa yang terkandung dalam rangkaian kata-katanya dan rangkaian kata-kata tersebut digunakan untuk mengingkari makna yang sebenarnya,
(Keraf, 2007). Terdapat 28 data dari keseluruhan data yang termasuk dalam kategori ini. Selain itu, analisis data juga menunjukkan adanya kategori satire berisi kritik terhadap sikap dan perilaku buruk. Hasil analisis menunjukkan bahwa 26 data dari total data termasuk dalam kriteria ini. Adapun pada kategori satire berisi kritik terhadap sikap dan perilaku buruk menggunakan bentuk ungkapan untuk menyapaikan makna kritik terhadap sikap dan perilaku buruk. Selanjutnya, tabel 3.1 menunjukkan secara rinci distribusi data kriteria satire.

Tabel 1. Distribusi data Kriteria Satire

\begin{tabular}{|l|c|c|}
\hline \multicolumn{1}{|c|}{ Kriteria satire } & $\begin{array}{c}\text { Jumlah } \\
\text { data }\end{array}$ & Presentase \\
\hline $\begin{array}{l}\text { Satir berisi kritik } \\
\text { terhadap sikap dan } \\
\text { perilaku buruk }\end{array}$ & 26 & $48,14 \%$ \\
\hline $\begin{array}{l}\text { Satire } \\
\text { menggunakan ironi }\end{array}$ & 28 & $51,85 \%$ \\
\hline
\end{tabular}

b. Kesepadanan Implikatur Kesepadanan implikatur yang dimaksud disini adalah hasil terjemahan satire yang menghasilkan bentuk implikatur pada teks sasaran. Hasil penelitian mengungkapkan bahwa semua 
tuturan satire merupakan tuturan dengan makna tersirat. Selain itu, hasil penelitian juga menunjukkan keberhasilan penerjemah dalam mempertahankan kesepadanan implikatur dalam teks bahasa sasaran. $100 \%$ tuturan satire dalam teks bahasa sumber tidak mengalami pergeseran implikatur dalam teks sasaran. Hal ini menunjukkan bahwa penerjemah berhasil menghadirkan kesepadanan implikatur dalam teks bahasa sasaran. Dengan kata lain, pada kategori kesepadanan implikatur ini penerjemah berhasil menghadirkan efek implikatur kepada pembaca sasaran. Selanjutnya, rincian analisis dapat dilihat pada table berikut.

Tabel 2. Distribusi data kesepadanan implikatur

\begin{tabular}{|l|l|l|}
\hline $\begin{array}{l}\text { Jenis Kesepadanan } \\
\text { Pragmatik }\end{array}$ & $\begin{array}{l}\text { Jumlah } \\
\text { data }\end{array}$ & Presentase \\
\hline Implikatur & 54 & $100 \%$ \\
\hline
\end{tabular}

Berikut contoh analisis dari kesepadanan implikatur yang terdapat dalam novel animal farm.

(1) Teks Sumber (TSu): We pigs are brainworkers.

Teks Sasaran (Tsa): Kami, kaum babi, merupakan kaum pemikir.
Pada contoh tuturan satire (1) diatas dikategorikan dalam bentuk conversational implikatur karena implikatur ini muncul dalam teks sumber yang merupakan bentuk komunikasi antara penulis dengan pembaca teks sumber dan teks sasaran yang merupakan bentuk komunikasi antara penerjemah dan pembaca sasaran. Selanjutnya, contoh (1) merupakan bentuk implikatur karena maksud tuturan tersebut tidak sesuai dengan makna kalimat penyusunnya. (Grice, 1975) menyatakan bahwa conversational implicature is implication or proposition in conversation which appears because of violating the conversational principle in which the speaker's intention is expressed differently in the speaker's actual utterance.

Pada analisis implikatur dibutuhkan analisis konteks yang terlibat dalam sebuah tuturan. Konteks adalah tanggung jawab pendengar yang akan mengakses informasi dengan memproses ucapan melalui asumsi yang dibuat oleh pembicara,(Black, 2006). Pada contoh di atas, penulis teks sumber menggunakan metafora pig untuk menggambarkan golongan yang mempunyai strata lebih tinggi dari golongan yang lainnya. Tuturan pig as brain worker juga mengandung maksud yang menegaskan bahwa pig bukan merupakan golongan pekerja. Oleh karena itu, tuturan pada teks sumber merupakan bentuk implikatur 
karena penggunaan metafora menyebabkan pesan yang dikandung dalam tuturan tersebut menjadi implisit. Adapun hasil terjemahan dalam teks sasaran juga menyajikan bentuk implikatur. Meskipun dalam konteks cerita novel tersebut penulis teks sumber menggunakan metafora untuk menggambarkan golongan tertentu, pada teks sasaran penerjemah juga tetap menghadirkan metafora untuk menggambarkan keadaan yang sama dengan teks sumbernya. Melalui metafora $b a b i$ penerjemah berusaha membuat maksud tuturan menjadi implisit sehingga pembaca teks sasaran tetap harus berusaha menginterpretasikan pesan tuturan melalui konteks yang dilibatkan dalam tuturan tersebut.

\section{c. Kesepadanan Ilokusi}

Kesepadanan pragmatik pada analsis terjemahan tuturan satire dalam novel animal farm juga ditunjukkan dengan kesepadanan ilokusi. Kesepadanan ilokusi dapat mambantu mengidentifikasi apakah satire dalam teks bahasa sumber mempunyai maksud yang sama dengan teks bahasa sasarannya. Ilokusi digunakan untuk mengetahui maksud tuturan yang ingin disampaikan oleh penuturnya.
Tabel 3. Distribusi data kesepadanan ilokusi

\begin{tabular}{|c|c|c|c|}
\hline $\begin{array}{l}\text { Jenis } \\
\text { kesepadanan } \\
\text { pragmatik }\end{array}$ & $\begin{array}{l}\text { Jenis } \\
\text { ilokusi }\end{array}$ & $\begin{array}{l}\text { Jumlah } \\
\text { data }\end{array}$ & Presentase \\
\hline \multirow{2}{*}{ Ilokusi } & Ekpresif & 41 & $79,92 \%$ \\
\cline { 2 - 4 } & $\begin{array}{c}\text { Represen } \\
\text { tatif }\end{array}$ & 13 & $24,07 \%$ \\
\hline
\end{tabular}

Tabel di atas menunjukkan distribusi data terkait dengan kesepadaan ilokusi. Pada tabel diatas dapat diamati jenis ilokusi yang digunakan dalam tuturan satire yaitu ilokusi expresif dan representatif. Tuturan satire yang mempunyai ilokusi ekspresif lebih dominan jika dibandingkan dengan tuturan satire yang berilokusi representatif. Hal ini disebabkan karena tuturan satire sebenarnya merupakan tuturan penilaian atas sebuah sikap atau perilaku sehingga illokusi tuturan satire lebih banyak berilokusi ekspresif. (Yule, 1996) menyatakan bahwa dalam melakukan tindakan ekspresif, penutur menyatakan apa yang dirasakannya. Penjelasan lebih rinci dapat dilihat pada contoh berikut:

(2) TSu: Man serves the interest of no creature except himself.

TSa: Bangsa manusia hanya mementingkan bangsa manusia, bukan bangsa lain.

(3) TSu: Lanterns in the stalls were forbidden to save oil. 
TSa: Lentera di kandang dilarang pasang demi garis politik hemat energi.

Pada contoh (2) dan (3) di atas dapat dilihat bahwa penerjemah berhasil mempertahankan kesepadanan ilokusi teks bahasa sumber kedalam teks bahasa sasaran. Ilokusi pada contoh (2) di atas merupakan ilokusi ekspresif dengan daya ilokusi mengkritik. Selanjutnya, penerjemah mampu menghasilkan kesepadanan ilokusi yang dapat membuat hadirnya efek satire yang sama pada teks sasaran. Adapun pada kasus data (3) penerjemah juga berhasil mempertahankan ilokusi pada teks sasaran. Data (3) termasuk kedalam ilokusi representatif dengan daya ilokusi menyatakan.

\section{d. Kesepadanan relevansi}

Kesepadanan jarak relevansi mengacu pada kesamaan konteks yang dilibatkan dan upaya pemrosesan. Pada analisis ini terdapat $90,74 \%$ data yang tidak mengalami perubahan jarak relevansi dan sisanya mengalami perubahan jarak relevansi. Perubahan jarak relevansi ini disebabkan karena penerjemah melibatkan konteks yang lebih banyak dalam teks terjemahan sehingga menyebabkan pembaca tidak memerlukan usaha yang keras dalam upaya memproses pesan. Namun demikian, tuturan-tuturan satire dalam teks sastra hendaknya tetap dipertahankan kesepadanan jarak relevansi karena perubahan jarak relevansi dapat mengakibatkan nilai estetika karya sastra menjadi berkurang.

Tabel 4. Distribusi data kesepadanan jarak relevansi

\begin{tabular}{|c|c|c|}
\hline $\begin{array}{c}\text { Jarak } \\
\text { Relevansi }\end{array}$ & $\begin{array}{c}\text { Jumlah } \\
\text { data }\end{array}$ & Presentase \\
\hline Tetap & 49 & $90,74 \%$ \\
\hline Berubah & 5 & $9,25 \%$ \\
\hline
\end{tabular}

(4) Tsu: (a) 'A bird's wing, comrades,' he said, 'is an organ of propulsion and not of manipulation. It should be therefore be regarded as a leg. (b) The distinguishing mark of Man is the hand, the instrument with which he does all his mischief.

Tsa: (a) Bangsa burung mula-mula menolak, karena mereka punya dua kaki. Tapi, Snowball bisa membuktikan, tidaklah begitu halnya. "Sayap burung, sahabat," kata Snowball, " merupakan alat penggerak, bukan alat untuk melakukan manipulasi. Karena itu, sayap mesti dianggap sama dengan kaki. (b) Ciri utama menandakan seorang bangsa manusia adalah tangan. Dengan tangan itulah mereka melakukan segala rupa kebejatan."

(5) TSu: (a) 'Now, comrades, what is the nature of this life of ours? (b) Let us 
face it, our lives are miserable, laborious and short. (c)We are born, we are given just so much food as will keep the breath in our bodies, and those of us who are capable of it are forced to work to the last atom of our strength; and the very instant that our usefulness has come to an end we are slaughtered with hideous cruelty. (d) No animal in English knows the meaning of happiness or leisure after he is a year old. No animal in England is free. The life of an animal is misery and slavery: that is the plain truth.

TSa: (a) Sekarang, hai sahabatsahabatku, apa itu sesungguhnya hakekat kehidupan kita? (b) Mari kita perhatikan baik-baik: hidup kita ini sebenarnya menyedihkan. Hidup kita ini terbebani kelewat banyak kerja keras. Hidup kita ini amat singkat! (c) Kita dilahirkan, kita dijejali makanan sekedar supaya kita bisa bernafas. Kita dijejali makanan hanya sekedar supaya kita sanggup dipaksa bekerja hingga titik akhir kekuatan kita. Dan begitu kekuatan kita sudah punah, begitu kita sudah sempoyongan, begitu kita sudah tertatih-tatih, tulang-tulang kita sudah rapuh dan berkarat, begitu kita sudah tidak punya makna sepeser pun, maka leher kita digorok dengan cara-cara keji. (d) Kita berpulang ke alam baka tanpa mampu menangisi nasib. Kita sudah tergencet hingga ampas-ampasnya. Martabat kita martabat kutu yang hina dina. (e)Tak ada seekor binatang di seluruh Inggris yang punya kesempatan mengecap kebahagiaan dan masa santai begitu umurnya sudah masuk satu tahun. Tak ada binatang di Inggris yang merdeka! (f) Kehidupan seekor binatang adalah mata rantai ratap kesedihan yang sambung bersambung, tak putusputusnya. (g) Kehidupan seekor binatang adalah kehidupan perbudakan! Camkan kata-kataku ini: Perbudakan! Dan itulah fakta, kalau kalian mau tahu. Itulah kebenaran yang telanjang bulat!

Contoh data (4) merupakan contoh data tuturan satire yang mempunyai kesepadanan jarak relevansi dengan teks sumbernya. Hal ini dapat dilihat dari konteks yang dilibatkan dalam tuturan satire tersebut. Pada contoh (4) yang merupakan tuturan satire adalah tuturan (b) dan konteks yang dilibatkan adalah tuturan (a). Adapun pada contoh data (5), penerjemah menambahkan konteks pada teks sasarannya. Tuturan satire pada teks sumber adalah tuturan (d) yang dalam menghasilkan tuturan (d) penulis teks sumber melibatkan tiga konteks yaitu tuturan (a),(b), dan(c). Namun demikian, pada teks sasaran hasil penerjemahan tuturan satire $(\mathrm{g})$ melibatkan 
konteks (a),(b),(c),(d),(e) dan (f) sehingga terjadi perubahan jarak relevansi pada data (5).

e. Frekuensi kesepadanan pragmatik

Berdasarkan analisis yang telah dilakukan, kesepadanan yang paling banyak dicapai adalah kesepadanan ilokusi dan kesepadanan implikatur. Penerjemah berhasil mempertahankan ilokusi dan implikatur dalam teks sasaran yang berakibat pada dapat dipertahankannya efek satire dalam teks sasaran. Selanjutnya. Penerjemah belum berhasil sepenuhnya dalam menghasilkan kesepadanan jarak relevansi dalam bahasa sasaran karena pada beberapa data penerjemah menambahkan konteks yang membuat pembaca sasaran lebih mudah dalam melakukan upaya pemrosesan. Namun demikian, pada konteks teks sastra perubahan jarak relevansi dapat mengakibatkan hilangnya nilai keindahan dari teks sastra tersebut.

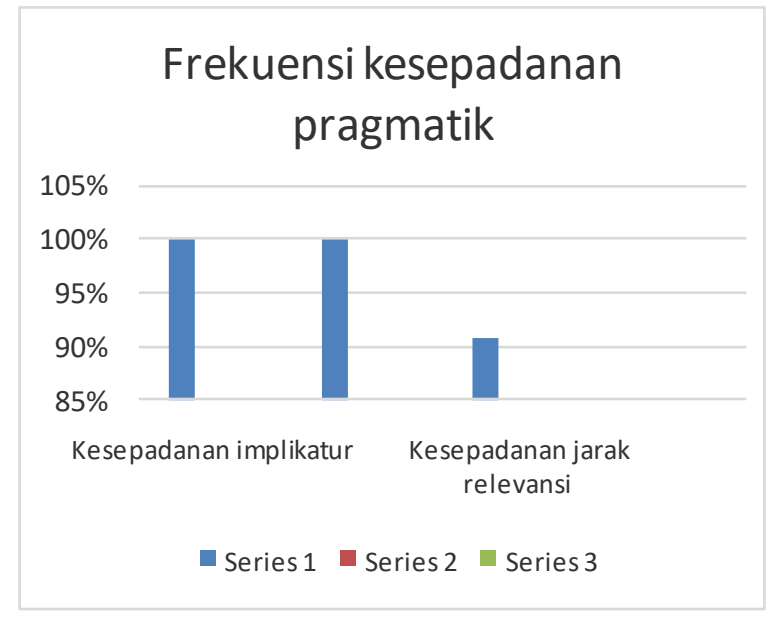

Gambar Frekuensi kesepadanan pragmatik
Pada gambar 3.1. diatas dapat dilihat distrubusi kesepadanan satire yang dihasilkan dalam penerjemahan teks karya sastra. Karena teks satire merupakan teks yang implisit yang digunakan untuk mengkritik sikap atau perilaku buruk maka sebagain besar pengungkapannya dalam bahasa sasaran juga menyuguhkan implikatur yang sama. Hal ini juga dapat dilihat dari penerjemahan tuturan humor yang sebagai besar juga diterjemahkan dengan bentuk implikatur yang sama dalam teks sasaran (Yuliasri, 2016).

\section{SIMPULAN}

Penerjemahan tuturan dalam teks karya sastra perlu mempertimbangankan konteks untuk mengungkapkan pesan dari tuturan-tuturan tersebut. Oleh karena itu, kerangka analisis pragmatik dapat dilibatkan untuk dapat menghasilkan terjemahan yang berkualitas. Selain itu, Pencapaian kesepadanan pragmatik khusunya dalam penerjemahan tuturan satire turut menentukan keberhasilan penyampaian maksud satire dalam teks terjemahan. Melalui kesepadanan pragmatik yang dihasilkan dalam teks terjemahan pembaca sasaran dapat merasakan efek satire yang sama dengan apa yang dirasakan oleh pembaca sumbernya. Dengan demikian upaya pengalihan pesan tuturan satire dalam 
teks karya sastra harus mempertimbangkan pencapaian kesepadanan pragmatiknya.

\section{DAFTAR PUSTAKA}

Aruna, U. (2018). Pragmatic Equivalance in Translation. Jurnal of Emerging Technologies and Innovative Research (JETIR), 5(189-194).

Black, E. (2006). Pragmatic Stylistic. Edinburgh University Press.

Catford, J. C. (1965). Language and Language Learning a Linguistic Theory of Translation. Oxford University Press, 110.

Chen, F. (2020). Study on pragmatic equivalence of computer aided translation. Journal of Physics: Conference Series, 1646(1). https://doi.org/10.1088/17426596/1646/1/012054

Grice, P. H. (1975). Logic and Conversation. Academic Press.

Jakobson, R. (1959). On Linguistic Aspects of Translation (pp. 232-239). Harvard University Press.

Keraf, G. (2007). Diksi dan Gaya Bahasa. PT Gramedia Pustaka Utama.

LeBoeuf, M. (2007). The Power of Ridicule: An Analysis of Satire. University of Rhode Island.

Levinson, S. C. (1991). Pragmatics. CUP.

Nida, E. A. (1964). Towards a Scince of Translating. E.J. Brill.

Searle, J. R. (1969). Speech Act: An Essay in the Philosophy of Language. Cambrige University Press.

White, H. D. (2011). Relevance theory and citations. Journal of Pragmatics,
43(14),

$3345-3361$. https://doi.org/10.1016/j.pragma.2011. 07.005

Wijana, I. D. P. (1996). Dasar-Dasar Pragmatik. Andi Offset.

Yule, G. (1996). Pragmatics. Oxford University Press.

Yuliasri, I. (2016). Translation Techniques and Pragmatics Equivalance in Indonesian Translation of Humorous Utterance in The Walt Disney's Donald Duck Comics. International Seminar Prasasti III, 409-414. 